\title{
Ideological and Political Construction of Concrete Structure Basic Principle Course
}

\begin{abstract}
Shi dandan ${ }^{1, \mathrm{a}}$
${ }^{1} X i$ 'an Traffic Engineering Institute

${ }^{a}$ Email: 2272088339@qq.com

ABSTRACT

The basic principle of concrete structure is a professional basic course of civil engineering discipline. The course is highly specialized, which makes it difficult to integrate the ideological and political content.This paper probes into the reform of ideological and political education in the course of basic principles of concrete structure from three aspects of course training objective, teaching scheme and implementation, and effect assessment.It can be seen from the implementation process and effect assessment that the reform of ideological and political education of this course is initially effective, which is an important step in ideological and political education of this course.
\end{abstract}

Keywords: Basic principles of concrete structure, Course education, Prestressed concrete

\section{INTRODUCTION}

For further study on the national provincial colleges and universities ideological and political work conference spirit, to carry out the spirit of national conference on education, promote the construction of universities education education teaching system, according to the $\mathrm{CPC}$ shaanxi provincial party committee of shaanxi province education department of education work committee on comprehensively promoting the construction of institutions of higher learning course ideological work plan notice requirements (no. 171 [2020]) file, Combined with the actual work of the school, the "Xi 'an Institute of Transportation Engineering Curriculum Ideological and Political Construction Implementation Plan (Revised)" has been formulated.According to the implementation plan, the ideological and political elements of the course of basic principles of concrete structure are explored. In the classroom teaching, ideological and political content and professional knowledge content are well integrated, and the "trinity" teaching objective of knowledge, ability and education is preliminarily realized [1]. This paper probes into the reform of ideological and political education in the course of basic principles of concrete structure from three aspects of course training objective, teaching scheme and implementation, and effect assessment.

\section{COURSE TRAINING GOAL}

\subsection{Knowledge goal}

In the design of the concrete structure, first of all, according to the functional requirements of the structure and consider the economic, construction and other conditions, choose the structure scheme and structure layout; Then, according to the load on the structure, the internal force analysis of the structure is carried out, and the internal force of the component section is obtained. The basic principle of concrete structure is on this basis, the structural design of all kinds of components of the composition of the structure, that is, to determine the number of steel bars required by the section, reinforcement and take the necessary structural measures, so the main knowledge of the basic principle of concrete structure course objectives are as follows:

(1) On the basis of learning the basic properties of reinforcement and concrete materials, the mechanism of force of members can be analyzed;

(2) in the grasp of the concrete members (bending, compression, tensile and torsional components) on the basis of the mechanical performance, combined with the static balance conditions to give the bearing capacity calculation formula and the applicable conditions, and then the section design and section review, so as to determine the section of the required number of 
reinforcement, reinforcement and the necessary structural measures;

(3) master the performance and design of prestressed concrete members.

\subsection{Ability goal}

The basic principles of concrete structure course competence objectives are as follows:

(1)Familiar with industry-related national policies, laws and regulations, have a strong sense of social responsibility and engineering professional ethics, and play a certain role for social progress [2];

(2) Have strong engineering practice ability, can use professional theoretical knowledge to deal with engineering practical problems, can be independent in engineering survey and design, construction and management, become the professional technology or management backbone of the unit;

(3) To have a good grasp of the development status of the discipline, be forward-looking in the future development trend, and actively promote the progress of professional technology;

(4) Have good comprehensive quality and international vision, be able to conduct cross-cultural communication, competition and cooperation well, become the main force to promote international exchange and cooperation, and more actively participate in the construction of "One Belt And One Road";

(5) Have a good sense of lifelong learning and innovation, adapt to the development of the industry and society, and formulate and implement career development plans.

\subsection{Educational goal}

Basic principle of concrete structure aims to develop to meet the need of social development, the morality, intelligence and physique, us, fatigue all-round development of the builder of the socialist modernization of [3], a solid grasp the theoretical knowledge, and have strong practical ability and innovation ability, to adapt to the construction engineering, highway and urban road construction and development needs of civil engineering applied talents with high quality. Specific education objectives are as follows:

(1) Be firm in ideals and beliefs, determined to take root among the people, contribute to the country, devote themselves to socialist construction, and have the courage to undertake the important task of national rejuvenation;

(2) A solid grasp of the basic principles of civil engineering disciplines, a wide range of and in-depth study of professional knowledge, professional skill practice training, and the ability to solve complex engineering problems and engage in civil engineering related professional work.

(3) I have a strong spirit of truth seeking and innovation, good humanistic feelings and scientific literacy, and strong critical thinking ability.

(4) Having a broad international vision, effective communication skills, autonomous and lifelong learning ability, and better adapt to the needs of the construction and development of civil engineering industry.

\section{TEACHING PLAN AND IMPLEMENTATION}

The excavation of ideological and political elements is the basis and key work of ideological and political teaching in the course.

\subsection{Introduction part of the teaching plan}

In the introduction part, the development history of the subject and the importance of course learning are mainly introduced[4]. The development history of concrete contains rich educational elements, so the content of this part is expanded, from the original one or let students study by themselves to a relatively detailed introduction of the development process and typical projects. When teaching this part of the content combined with the characteristics of the course gradually natural transition to ideological and political education issues. In terms of housing construction in residential and public building, guangzhou west tower in our country, for example, the building is adopted in the cylinder tube system, outer barrel for cross steel tube concrete inclined column grid, inner barrel is reinforced concrete structure, modelling is novel, as shown in figure 1[5], with the introduction of the project stimulate students' exploration spirit and innovation consciousness. In terms of bridge engineering, the Hong Kong-Zhuhai-Macao Bridge, with a total length of $55 \mathrm{Km}$, is the longest sea-crossing bridge in the world at present, as shown in Figure 2. The construction environment of the building is complex and the technology is difficult. The construction staff has carried out more coordination and management work, so as to cultivate students' hard-working spirit and courage to face the difficulties. 


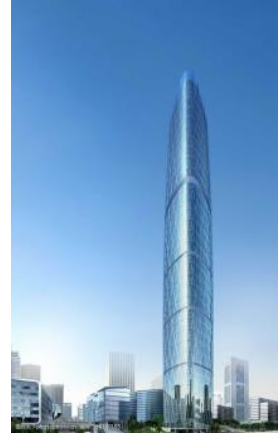

Figure 1 Guangzhou west towe.

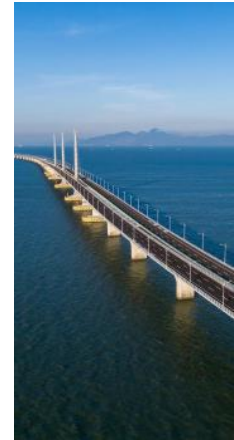

Figure 2 Hong KongZhuhai-Macao Bridge.

\subsection{Reinforcement and concrete material properties section teaching program}

The part of engineering materials mainly involves the performance characteristics and technical indexes of reinforcement and concrete. This part of teaching combined with engineering examples and test process, give concrete and steel performance characteristics. For example, through the compression test of reinforced concrete test blocks, the performance characteristics of high compressive strength of concrete and high tensile strength of reinforcement are given, as shown in Figure 3 and Figure 4.
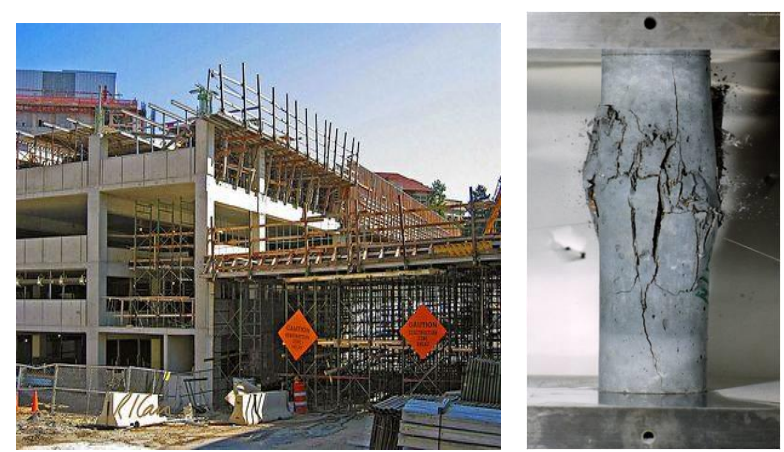

Figure 3 Frame column. Figure 4 Column destruction.

Introduce the purpose and course of China's main material reform, guide students to think about environmental problems, cultivate professional quality and social responsibility [6]; Through pictures or videos of engineering accidents, such as building collapse caused by insufficient concrete strength in different places, students will discuss and analyze the causes of the accidents and the responsibilities they should take after the accidents, so as to cultivate students' safety awareness and responsibility.

\subsection{Component performance and design part teaching program}

The basic principle of concrete structure is to solve the bearing capacity and deformation calculation of all kinds of components. When explaining the mechanical performance of all kinds of components, bearing capacity calculation and other knowledge points, through the introduction of engineering accident cases due to less distribution and leakage of stress reinforcement in engineering design and construction, the cause of the accident is analyzed. Guide students to think about how to prevent the occurrence of accidents and accidents when the response measures, so as to stimulate students' interest and enthusiasm in learning, deepen students' grasp and understanding of concrete member design methods, cultivate students' professional awareness and professional ethics, enhance the sense of social responsibility and mission. Through the study and application of Code for Design of Concrete Structures, Code for Load and relevant laws and regulations and national standards, the quality of students to strictly abide by the norms and standards is cultivated, and the consciousness of law-abiding is enhanced[7].For example, the "Code for Design of Concrete Structures" gives the reinforcement ratio of longitudinal tensile reinforcement of flexural members(Equation (1)),

$\rho=\frac{\mathrm{A}_{\mathrm{s}}}{\mathrm{bh}_{0}}(\%)$

In the formula: $\rho$ - reinforcement ratio;

$\mathrm{A}_{\mathrm{s}}$-Total cross-sectional area of longitudinal tensile reinforcement;

b - section width

$\mathrm{h}_{0}$ - Effective height of section

In addition, in the design of structural components, usually the result of reinforcement calculation for a component is not the only one, there are a variety of reinforcement schemes, which inspire students' critical thinking ability.

\subsection{Performance and design of prestressed component teaching program}

According to "10 New Technologies in Construction Industry (2017 Edition)" issued by the Ministry of Construction, prestressed concrete technology is also listed as one of them, which is widely used in construction engineering and bridge engineering. In the teaching of this part, the application process of prestressing is described by means of animation simulation. The loss of prestress is the key content of this part. Through the analysis of the causes of the loss of prestress, the combination of the loss values of prestress in each stage is given, as shown in Table1. 
Table 1. The combination of prestress loss values at each stage

\begin{tabular}{|c|c|c|}
\hline $\begin{array}{c}\text { Combination of } \\
\text { prestress loss } \\
\text { values }\end{array}$ & $\begin{array}{c}\text { Pre-tensioning } \\
\text { components }\end{array}$ & $\begin{array}{c}\text { Post } \\
\text { tensioning } \\
\text { member }\end{array}$ \\
\hline $\begin{array}{c}\text { Loss of } \\
\text { concrete } \\
\text { before } \\
\text { preloading } \\
\text { (first batch) }\end{array}$ & $\sigma_{l 1}+\sigma_{l 2}+\sigma_{l 3}+\sigma_{l 4}$ & $\sigma_{l 1}+\sigma_{l 2}$ \\
\hline $\begin{array}{c}\text { Loss of } \\
\text { concrete after } \\
\text { preloading } \\
\text { (second lot) }\end{array}$ & $\sigma_{l 5}$ & $\sigma_{l 4}+\sigma_{l 5}+\sigma_{l 6}$ \\
\hline
\end{tabular}

\subsection{Part of the teaching plan of the experimental course}

Curriculum ideology and politics can not only be reflected in the theory class, but also in the experimental class. The course of principle of concrete structure design has some experimental hours, and the ideological and political elements integrated in the experimental process are as follows:

(1) Students participate in preparation work such as specimen making and parameter input of experimental instruments. Full preparation work determines the success of the experiment, so that students can realize that the preparation work in the early stage of anything plays an important role in the success of things.

(2) In the bending experiment of the normal section of the simply supported beam, the accurate experimental data depends on the reasonable experimental scheme, so that students can understand that researchers should have a rigorous attitude towards science, and then cultivate students' scientific literacy;

(3) In the axial compression experiment of the column, students are assigned tasks, and each load can be rotated to ensure that every student is involved in the experiment, so that students can master the experimental skills comprehensively and cultivate the spirit of unity and cooperation at the same time;

(4) Consciously cultivate students to establish the concept of green environmental protection in the stacking and disposal of discarded specimens.

Experiment teaching system is students to master professional skills, the important way to improve the beginning ability, component design through the experiment, experiment design, experiment preparation, implementation, experimental analysis, write test report and other multiple link team division of labor cooperation practice, let students experience the professional role responsibilities job requirements and the specific implementation process. Through project practice, on the one hand, students' practical ability, communication and cooperation, organization and coordination, and ability to solve practical problems can be improved, and basic skills training of engineers can be obtained[8]. On the other hand, students can be cultivated to develop a meticulous spirit, serious and responsible work attitude, and the pursuit of excellence.

\section{EFFECT ASSESSMENT}

Through the combination of knowledge imparting and ideological and political elements in the classroom education form, change the simple theoretical preaching teaching mode, update the teaching content, enrich the teaching means, use of new media technology to achieve the benign interaction between teachers and students, a better completion of the ideological and political objectives of the course. Main Ideological and Political Achievements of the Course of Basic Principles of Coagulation Structure:

(1) Through the organic integration of professional knowledge and skills with ideological and political content in classroom teaching, students' learning attitude is correct, their interest in professional courses is enhanced, and their mastery of professional knowledge is also enhanced;

(2) Through the study and application of "Code for Design of Concrete Structures", "Code for Load" and relevant laws and regulations and national standards, establish the consciousness of professional ethics and abide by the code of professional ethics. In the architectural design, construction and supervision work, strictly in accordance with the norms and standards;

(3) Actively participate in social practice and innovation and entrepreneurship training, optimistic and confident, ambitious, clear goals, and achieve breakthrough achievements in discipline competitions;

(4) Actively participate in public welfare activities. For example, when I went to a nursing home to volunteer for public welfare, the students' selfless dedication and hard-working behavior reflected a strong patriotic feeling.

\section{CONCLUSION}

This paper probes into the reform of ideological and political education in the course of basic principles of concrete structure from three aspects: training objective, teaching scheme and implementation, and effect assessment. It can be seen from the implementation process and effect assessment that the reform of ideological and political education of this course is initially effective, which is an important step in ideological and political education of this course. But the depth and breadth are still insufficient, in the future 
"teaching and educating people" work, still need to study the ideological and political elements, the whole process of curriculum ideological and political education, the formation of professional education and ideological and political education organic unity.

\section{REFERENCES}

[1] Fu Xianghong, Huang Yanxia. Research on Ideological and Political Construction of Concrete Structure Design Principle Course [J]. Journal of Anyang Normal University, 2021,(02):138-141.

[2] LI Zheng. Discussion on Ideological and Political Teaching of Concrete Structure Design Principle Course [J]. Science and Education Guide, 2020, 000(004):119-121.

[3] Kang Yumei, Wang Yanbang, Chen Meng. Ideological and political reform and practice of specialized courses based on category ideological and political elements $[\mathrm{J}]$. Journal of Liaoning Institute of Educational Administration, 2020(05):53-56.

[4] Liu Jianping, Shi Ping. Reform and practice of ideological and political education in the course of "Principles of Concrete Structure Design" in colleges and universities $[\mathrm{J}]$. Education Modernization, 2019(56):106-107+115.

[5] Yan Qiwu, Liu Shu, Zhou Chaoyang. Research on the Construction of the Excellent Course of Design Principle of Concrete Structure $[\mathrm{J}]$. Journal of Changsha Railway University (Social Science Edition), 2009(001):50-52.

[6] Liu Yujuan. Research on the Teaching Reform of Concrete Structure Design under the Course Ideological and Political Idea [J]. Sichuan Cement, 2020, 000(004):73-99.

[7] Lu Zheng, Lin Jiali. Discussion on the Ideological and Political Construction Path of Civil Engineering Specialty Course -Taking Construction Engineering Law Course as an Example [J]. Higher Architectural Education, 2020(3).

[8] HLi Shengyong, Zhu Dongmei. Research on the Ideological and Political Construction of Hydraulic Reinforced Concrete Structure Course [J]. Knowledge Library, 2020(03):205-206. 